\title{
Assessment of Quality of Internet Service Delivery in Selected Southwestern Universities in Nigeria
}

\author{
Bosede B. Fasiku \\ Information and \\ Communication Unit \\ Obafemi Awolowo University, \\ lle-Ife
}

\author{
Michael O. Awoleye \\ African Institute for Science \\ Policy and Innovation, \\ Obafemi Awolowo University, \\ lle-Ife
}

\author{
Timothy O. Oyebisi \\ African Institute for Science \\ Policy and Innovation, \\ Obafemi Awolowo University, \\ lle-Ife
}

\begin{abstract}
This study examines types of Internet services available, frequency of use of the same, and also determines the quality of Internet delivered in the selected Universities in Southwestern Nigeria. The research design employed by this study is survey method, using questionnaire instrument. Three universities were selected, these include: Obafemi Awolowo University (OAU) Ile-Ife, Ekiti State University (EKSU) AdoEkiti and BOWEN University (BU), Iwo. The research adopted reliability, responsiveness, tangibility, empathy and assurance as metrics to measure the dynamics of the services delivered in the selected universities. The research purposively sampled four hundred academic and nonacademic staff including students in the selected universities. The findings show that Internet services which are mostly web related were present in the selected Institutions. The research specifically indicated that $97.6 \%$ of the respondents use World Wide Web (WWW), followed by e-mail (87.3\%) and instant messaging (54.6\%). Daily use of WWW mainly characterises the frequency of use of the services. This is followed by e-mail, which is been used daily and sometimes weekly. The overall quality of Internet services delivered was noted to be somewhat impressive when considering some indicators such as responsiveness and competencies of the staff responsible to providing the service. On the other hand, when considering information management, especially dissemination of information to users regarding downtime, schedule maintenance and other forms of bottlenecks were noted to be poor. It is therefore imperative for the stakeholders in the higher institutions, especially the top management to ensure that they continue to support free flow of Internet services, since this has the tendency to impact the productivity of the members of the University community at large.
\end{abstract}

\section{General Terms}

Internet service delivery, Quality of Service (QoS), Internet diffusion.

\section{Keywords}

Internet services, Quality of Service, Internet assessment, Nigeria, Universities.

\section{INTRODUCTION}

Information Communications Technology (ICT) is an important part of today's life. Information flow is very crucial for the growth and development of any institution of higher learning. The advent of the Internet in the $21^{\text {st }}$ century has improved academic and social lives of students in the educational sphere. The benefit of the Internet and its impacts on learning has attained more popularity in many countries globally, Nigeria is no exception (Awoleye et al., 2006). The Internet has contributed to making teaching and learning easier and cheaper to achieve, compared to the era before the advent of the Internet. The Internet today has presented itself as a veritable source of information and channel of communication that has enabled students, staff and researchers access all sorts of relevant data and information. Ogunlade et al. (2013) carried out a similar research on the assessment of the Internet service quality and customer's satisfaction as a case study of University of Ilorin but the assessment was limited because of its scope. However, no recent research has been conducted to compare the quality of Internet service delivery among selected Universities in Nigeria. Service delivery is the successful delivery of excellent service to users. It is the act of offering consistent service to customers. In the context of Universities in Nigeria, Internet Maintenance Unit (IMU) is the unit in charge of the Internet service delivery in the universities. Some universities may have other names for it but the functions are still related. This unit represent the Internet Service Provider (ISP) in all the universities since its role is to provide and maintain Internet services within the University. The IMU charged the subscribers/users a little amount of money as monthly subscription. It is also an expectation for these IMUs to provide a reliable and dependable service to the users. Gee et al. (2008) in their studies shows that the quality of service delivered positively influence the satisfaction of their subject. It is worth noting to state that consumer satisfaction has significant effect on customer loyalty, and in return increase the profitability of the provider organization. This study assesses the quality of the Internet service delivery in selected southwestern Nigeria universities based on reliability, responsiveness, tangibility, empathy and assurance metrics.

Several studies had been conducted on the Internet usage in the Universities (Awoleye, et al., 2006, 2008, Otunla, 2013). In the study to compare Internet and Library use among undergraduate students, the findings revealed that students make use of the Internet more than they use the Library (Kumah, 2015). In addition, in a study on the Internet access and use among undergraduate students of Bowen University in Iwo, Osun state, the results proved that the Internet has a positive impact on their academic performance (Otunla, 2013). In the same vein, a study on Internet and its use in the Engineering College of Punjab shows that majority of the students acknowledged that the Internet is very useful, easy and time saving (Kumar and Kaur, 2005). In all of these, no research was carried out to assess the Internet service delivery in Nigeria universities. In this context, this work is positioned to serve as baseline for analysis and assessment of the Internet service delivery, especially in Southwestern universities in Nigeria. In order to do this in the selected universities, answers were sought to the following research questions: (i) what are the types of Internet service delivered in the selected southwestern Universities? (ii) what is the pattern of use of 
the chosen Internet services among the selected institutions? (iii) what is the quality of the Internet services delivered in the selected universities? The specific objectives of the study are therefore to: (i) analyze the types of Internet services delivered in the selected Universities in Southwestern Nigeria (ii) examine the pattern of use of Internet Services (iii) assess the quality of service delivered in the selected Universities.

\section{LITERATURE}

This section discusses related literatures which covers (i) the trajectory of Internet services in Nigeria (ii) the service quality ecosystem within the same space (iii) customer satisfaction and loyalty and (iv) determinants of service quality.

\subsection{Trajectory of Internet Services in Nigeria}

Researchers have shown that ICT is now a means of expanding educational opportunities, and many universities globally are now ICT compliant (Awoleye et al., 2006, 2008). This has greatly replaced the old system of teaching and research methods. Mereku et al. (2009) reported that at the tertiary level, most ICT literate students and scholars have their own tools for accessing the Internet. They have access to own computers and the Internet was reportedly available within their community. The use of the Internet was noted to be mainly for searching teaching and learning materials, which they use to enrich the contents of their work. There is increasing penetration of Information and Communication Technology (ICT) throughout university education worldwide is in line with UNESCO's policy for change and development in tertiary institutions (UNESCO, 2013) This has encouraged tertiary educational institutions to make greater use of the opportunities created by the advancement of communication technology to improve and enhance the quality of education and its delivery. The Internet has provided the scholars and researchers several opportunities in many ways to exchange ideas globally on different fields of study. This has allowed the students and lecturers to communicate both locally and internationally. The Internet is an important component of academic institutions because of the role it plays in meeting information and communications needs. The Internet supports scholars and academic institutions to disseminate information to a distance audience through skype, hosting websites and telepresence. In addition, students and lecturers in Nigeria universities can communicate seamlessly via the Internet irrespective of geographical boundaries. Distance learning was also being facilitated by the Internet (Awoleye et al., 2007).

\subsection{Service Quality ecosystem}

According to Fogli (2006), service quality is a global judgement or attitude towards a particular service. That is customer's final impression of the inferiority or superiority of the organization and its services. Customers or users expect the organization to pay attention to their problems and deliver products and services that meet their needs. However, it is the assessment of the service quality that leads to customer's satisfaction. Without a strong service delivery strategy, it is easy to overpromise and not be able to deliver (Zuzana, 2013). A research by Parasuraman et al. (1990) explains the key determinants of service quality.

\subsection{Customer satisfaction and loyalty}

Chakrabarty (2006) defines customer satisfaction as how a product or service surpasses customer's expectation. This further means the ability of the service to meet the customer's needs and expectations. Customer satisfaction means feeling of excitement, happiness, acceptance, and relief. Zeithaml et al. (2009) confirms that customer satisfaction helps in identifying the areas for improvements as well as meeting the customer's needs. The provision of an organization quality services or not depends on the customers' feedback on the satisfaction they perceive after consuming the service (Kotler and Keller, 2009). Hansemark and Albinson (2004) expresses satisfaction as an overall customer's feelings toward a service provider or their reaction to the difference between customer's expectation and what they receive, regarding the fulfillment of their promises and goals.

\subsection{Determinants of Service Quality}

Determinants of service quality have been identified in literature as embodiment of empathy, reliability, responsiveness, tangible and assurance. This is further expatiated as follows. Empathy is an act of showing care and paying attention to customers. Bennett et al. (2002) in their study, itemized the strategies used by service organizations to show empathy. These include service offerings to individual customers, making customers feel important by developing long-term relationships, by responding to their needs and understanding their concerns. Reliability is the ability to deliver a promised service dependably and accurately. The strategies for ensuring reliability is to understanding customers' needs and want through market research. There is need for consistency to ensure that the promises made in marketing communication are realistic and achievable, and managing customer expectations of the reliability of the service (Rasli et al., 2012). Responsiveness is the ability of the service provider to help customers willingly and provide prompt service (Rasli et al., 2012). The strategies for increasing responsiveness include individualizing the service as much as possible; determining the customer's views about the service; constant training of staff so that they can respond when necessary; and ensuring that customers do not have to wait too long for assistance or to receive the service. Tangible is viewed as physical facilities, equipment and appearance of staff (Rasli et al., 2012). The strategies relevant to managing the tangibility of services include buildings, interior, exterior, furniture, equipment, and colors; and giving customer's tangible items as a record of the service transaction, for example brochures, business cards, receipts and documents. While assurance is described as the ability of the employees to inspire trust and confidence on their customers (Rasli et al., 2012). The strategies for assuring customers include creating trust and confidence through the knowledge and skills of contact personnel and creating continuity of service staff. Others includes creating an organization-wide image that reflects the core values of the organization, building a strong corporate brand image; and using clues such as employee dress appearance of the interior and exterior of the firm, employee attitudes, visible qualifications and credentials, and pleasant surroundings to reassure the customer.

\section{RESEARCH METHODOLOGY}

The study employed majorly descriptive statistics which include frequency counts, percentages and means. The population of this study was drawn from an unknown spread of Internet users in 160 Universities in Nigeria. A sample of 400 respondents were purposively drawn from three Universities in Southwestern Nigeria this include OAU, EKSU and BOWEN. The choice of Southwestern region out of the six geo-political zones of Nigeria was purposive. The Southwestern region was noted to be the region with the highest concentration of the educated elites in Nigeria. 


\subsection{Research Instrument}

A well-structured questionnaire instrument was designed and it targeted researchers which include the academic staff, nonacademic staff and students of the Universities. The main questionnaire has three sections. Section A was for the respondents' socio-demographic data which included gender, age, qualification and category of the respondents. Section B shows the types of Internet services delivered and how it is used. The last section determines the qualities of service delivery and the factors influencing the delivery of the service in these universities.

\subsection{Variable description}

Some Internet services were listed (see Table 2) which the respondent were requested to tick the relevant ones available in their institutions. This was thereafter aggregated by frequency count and percentages. To capture the frequency of use of these Internet services, average mean was employed to ascertain the frequency of use of the available Internet services (see Table 3). A five-point likert-type scale was used, which are: daily (5), weekly (4), bi-monthly (3), monthly (2), never (1).

These variables were measured with respect to the usage of the Internet services in each of the institutions. WWW, Electronic mail (email), chatroom, instant message, file sharing, blogging and gaming for types of the Internet services delivered. Moreover, for quality of services the variables include reliability, credibility, willingness, promptness, competence and recommendation among others. Lastly, the quality of service was measured as well using two categories of scales. The first category employed a 5-point likert type scale (see Table 4). For example, 'Reliability of the ISP' as an indicator ranges from very reliable (5) to poor reliability (1). 'Reliability of the ISP' also ranges from very swift (5) to Non-challant (1), while the indicator 'empathy/care' also ranges from excellent (5) to poor (1). The second category which include ISP: credibility, competency, willingness, information dissemination, recommendation of ISP, preference to other ISPs, Service worth paying for, switching of ISP were dichotomous which were represented by either a 'yes' or 'no'.

\subsection{Data collection and Analysis}

Data were collected by direct administration. The instrument was administered to respondents and retrieved immediately after the respondents had completed them. Data collected for the study were analyzed using descriptive statistics.

\section{RESULTS AND DISCUSSION}

\subsection{Profile of the respondents}

Table 1 shows the percentage distribution of the respondents in the universities. The study surveyed 400 respondents from the three selected universities in Southwestern Nigeria, namely

Table 1: Percentage Distribution of the respondents in the Universities

\begin{tabular}{|c|c|c|c|}
\hline University & Spread & Retrieved & Rate $(\%)$ \\
\hline OAU & 180 & 150 & 45.45 \\
\hline EKSU & 130 & 110 & 33.30 \\
\hline BOWEN & 90 & 70 & 21.20 \\
\hline Total & 400 & 330 & 100 \\
\hline
\end{tabular}

Source: Author's field work

OAU, EKSU and BOWEN. The demographic information of the respondents include the following: age, gender, category of respondents and educational status. From the 400 respondents, 330 completed questionnaire were returned which represents $82.5 \%$ of the respondents. The returned questionnaire shows that $150(45.5 \%)$ were from $\mathrm{OAU}, 110$ (33.3\%) from EKSU and 70 (21.2\%) from Bowen University respectively. Majority of the respondents are male and this comprise academic staff, non-academic staff and students.

\subsection{Types of The Internet Services delivered}

The study revealed that there is no difference in the types of the Internet service delivered among the three universities. Table 2 shows that WWW is the most popular Internet service delivered among the selected Universities. For example, in Table 2 the result shows that $95.7 \%$ of the respondents from BOWEN reported that WWW was the Internet service that were most available. In the same vein, 96.4 and $99.3 \%$ of the respondents in EKSU and OAU, respectively have similar experience. It was also noted that $75.7 \%$ of the respondents from BOWEN reported the availability of e-mail as part of the Internet services provided in the institution. So also, 94.6 and $87.3 \%$ of the respondents from EKSU and OAU reported that e-mail was part of the Internet services that were widely provided within the University community. In addition, $54.3 \%$ of the respondents from BOWEN reported that instant messaging was also allowed as an Internet service provided on the University Internet network. Similar reports were noted for both EKSU and OAU which stood at 50.9 and $57.3 \%$ respectively in both Universities. Other services provided among others are: web services which include but not limited to chat rooms, blog postings and file sharing.

Table 2: Type of Internet Services delivered across the Selected Universities

\begin{tabular}{|c|c|c|c|c|}
\hline $\begin{array}{c}\text { Internet } \\
\text { Services }\end{array}$ & BOWEN & EKSU & OAU & Total \\
\hline & $\begin{array}{c}\text { Freq. } \\
(\boldsymbol{\%})\end{array}$ & Freq. (\%) & Freq. & Freq. \\
$\mathbf{( \% )}$ & $(\boldsymbol{\%})$ \\
\hline WWW & $67(95.7)$ & $106(96.4)$ & $149(99.3)$ & $322(97.6)$ \\
\hline E-mail & $53(75.7)$ & $104(94.6)$ & $131(87.3)$ & $288(87.3)$ \\
\hline $\begin{array}{c}\text { Instant } \\
\text { messages }\end{array}$ & $38(54.3)$ & $56(50.9)$ & $86(57.3)$ & $180(54.6)$ \\
\hline $\begin{array}{c}\text { Chat } \\
\text { room }\end{array}$ & $34(48.6)$ & $54(49.1)$ & $60(40.0)$ & $148(44.9)$ \\
\hline Blogs & $36(51.4)$ & $2(1.8)$ & $59(39.3)$ & $97(29.4)$ \\
\hline $\begin{array}{c}\text { File } \\
\text { sharing }\end{array}$ & $29(41.4)$ & $10(9.1)$ & $57(38.0)$ & $96(29.1)$ \\
\hline $\begin{array}{c}\text { Online } \\
\text { shopping }\end{array}$ & $28(40.0)$ & $4(3.6)$ & $46(30.7)$ & $78(23.6)$ \\
\hline Gaming & $25(35.7)$ & $5(4.6)$ & $42(28.0)$ & $72(21.8)$ \\
\hline Total & 310 & 341 & 630 & 1281 \\
\hline
\end{tabular}




\subsection{Frequency of use of Internet services across the selected Universities}

Table 3 shows that respondents from BOWEN (4.51), EKSU (4.53) and OAU (4.78) used the WWW on daily basis. Furthermore, OAU had the highest mean which indicated that majority of the respondents in OAU seem to use the service on a daily basis more than their counterparts in BOWEN and EKSU. This is not surprising because, it has been previously documented by other researchers that OAU is a leading University when it comes to ICT infrastructure, deployment and its use (Awoleye, 2006, 2007, 2008; Jagboro, 2007; Ademola, 2013).

Regarding e-mail services, all the selected schools made use of it on a daily basis, although BOWEN had the lowest mean (3.94) while OAU had the highest mean (4.37). Notwithstanding, this thus suggest that respondents in these selected institutions agreed that the use of e-mail is a daily affair. With respects to chatting, respondents in all the schools reported that they sparingly utilize this facility, as this was noted to be done mostly bi-monthly as shown in Table 3. For

Table 3: Use of the Internet Services delivered among the Selected Universities

\begin{tabular}{lrrrr}
\hline Internet & BOWEN EKSU & OAU & Total Mean \\
\multicolumn{5}{c}{ Services } \\
\hline WWW & 4.51 & 4.53 & 4.78 & 4.64 \\
E-Mail & 3.94 & 4.28 & 4.37 & 4.25 \\
Chat & 2.81 & 3.15 & 2.72 & 2.89 \\
Instant & 3.16 & 3.07 & 3.15 & 3.12 \\
& \multicolumn{5}{c}{ message } \\
File sharing & 2.57 & 1.77 & 2.41 & 2.23 \\
Online & 2.37 & 1.16 & 1.89 & 1.75 \\
& \multicolumn{5}{r}{ Shopping } \\
Blogs & 2.60 & 1.10 & 2.38 & 2.00 \\
Gaming & 2.41 & 1.18 & 2.01 & 1.82 \\
\hline
\end{tabular}

LEGEND: Daily $=5$, Weekly $=4$, Bi-Monthly $=3$, Monthly $=2$, Never $=1$

other services provided, Table 3 also shows clearly that other services being provided were used differently by these Institutions. For example, BOWEN, EKSU and OAU utilized instant message bi-monthly given the mean 3.16, 3.07 and 3.15 respectively. The results also shows that respondents from BOWEN were using file sharing on bi-monthly basis, while respondents from EKSU and OAU used it on monthly basis. As regards online shopping, the result shows that respondents from BOWEN and OAU utilized online shopping on monthly basis while EKSU never used online shopping. Considering blogs, respondents from BOWEN utilized blogs twice a month, EKSU never utilized blogs and OAU utilized it monthly. All of these differences noted in the use of Internet services among the selected Universities may not be unconnected with Infrastructural capability, staff competences and support from individual University top management.

\subsection{Quality of Internet Service delivery in selected Universities}

The distribution of the quality of the Internet service indicators are presented in Table 4. The result shows that more than half $(55.7 \%)$ of the respondents from BOWEN indicated that the Internet service provisioning is reliable while $60.9 \%$ of the respondents from EKSU and $43.3 \%$ of the respondents from OAU have similar opinions that the ISP is somewhat reliable. And on the attitude towards solving Internet issues, about three quarter $(72.9 \%)$ of the respondents from BOWEN, $100 \%$ from EKSU and $69.3 \%$ from OAU reported that ISPs have positive attitude towards solving issues. Regarding their responsiveness relative to problem reporting and response time, more than half across the three selected Universities reiterated that the ISPs are quite fast (responsive) as shown in Table 4. Among the respondents from BOWEN $75.7 \%$ of them indicated that their Institution's ISP is credible. The same was also reported for both EKSU $(78.7 \%)$ and OAU $(85.2 \%)$. About the competency of the ISPs across the institutions, Table 3 further shows agreement on this indicator as this stood at 72.9, 100 and $79.3 \%$ in BOWEN, EKSU and OAU respectively. However, ISP does not keep the respondents informed when there is network outage as indicated by $57.1,80.9$ and $70.7 \%$ respectively from BOWEN, EKSU and OAU.

\section{SUMMARY AND CONCLUSION}

\subsection{Summary}

The research was set to identify the types of internet services provided in three selected institutions in southwestern Nigeria. It also examined the frequency of use as well as the quality of service of the services provided in the selected area. The findings indicated that WWW, e-mail and instant messages were the major and prevalent Internet services delivered. On the interaction of the respondents to the services provided, which has to do with the frequency of use of the services. It was reported that the respondents used the leading service (WWW) widely on a daily basis across the Universities selected. The same goes for e-mail service, which was also used on daily basis. On Instant messages, it was noted that this service was used on average $(54.3,50.9$ and $57.3 \%)$ bimonthly in in BOWEN, EKSU and OAU, respectively. This is consistent with the finding of Ogungbemi et al. (2016) on the Internet use among Nigeria undergraduates, which proved that most staff and students use the Internet every day. This shows that the use of the Internet is now inevitable on a daily basis, especially among undergraduates in Nigeria. On the quality of service delivery in the selected institutions in the study area, the research found that the Internet is quite reliable. Even when there is a bottleneck or any form of breakdown leading to deprivation of Internet flow, the responsiveness was reportedly impressive. One major challenge as noted by this research which was a deficiency from the ISPs has to do with Information management. They seem to be non-challant as to keep the users informed of any maintenance schedule or general failure, which may also be a problem from the upstream provider.

\subsection{CONCLUSION}

Following the available Internet services provided in the selected Institutions as noted in the study, as well as the pattern of Internet service use and the quality of Internet services provided. The IMU in each university should improve more on the optimal quality of services to prevent the occurrence of dissatisfaction of customers, which could lead to decreased customer loyalty. In the same vein, it is 
imperative for the stakeholders in these institutions to ensure adequate maintenance for the existing infrastructure as well as endeavor to keep the pace of technical competencies and to improve on technical support including information

Table 4: Quality of Internet Service Delivery in the Selected Universities

\begin{tabular}{|c|c|c|c|c|}
\hline & BOWEN & EKSU & OAU & Total \\
\hline & Freq. (\%) & Freq. (\%) & Freq. (\%) & Freq. (\%) \\
\hline \multicolumn{5}{|c|}{ Reliability of the ISP } \\
\hline Very reliable & $5(7.1)$ & $38(34.5)$ & $28(18.7)$ & $71(21.5)$ \\
\hline Reliable & $39(55.7)$ & $67(60.9)$ & $65(43.3)$ & $171(51.8)$ \\
\hline Slight reliable & $21(30)$ & $2(1.8)$ & $40(26.7)$ & $63(19.1)$ \\
\hline Not reliable & $3(4.3)$ & $3(2.7)$ & $12(8.0)$ & $18(5.5)$ \\
\hline Poor & $2(2.9)$ & - & $5(3.3)$ & $7(2.1)$ \\
\hline \multicolumn{5}{|c|}{ Responsiveness of ISP } \\
\hline Very swift & $10(14.3)$ & $40(36.4)$ & $21(14)$ & $71(21.5)$ \\
\hline Fast & $41(58.6)$ & $60(54.5)$ & $80(53.3)$ & $181(54.8)$ \\
\hline Very Slow & $18(25.7)$ & $10(9.1)$ & $44(29.3)$ & $72(21.8)$ \\
\hline Slow & & & & \\
\hline Non-Challant & $1(1.4)$ & - & $5(3.3)$ & $6(1.8)$ \\
\hline \multicolumn{5}{|l|}{ Empathy/ Care } \\
\hline Poor & $2(2.9)$ & - & $8(5.3)$ & $10(3)$ \\
\hline Fair & $7(10)$ & $5(4.5)$ & $18(12)$ & $30(9.1)$ \\
\hline Good & $31(44.3)$ & $38(34.5)$ & $67(44.7)$ & $136(41.2)$ \\
\hline Very good & $20(28.6)$ & $63(57.3)$ & $42(28)$ & $125(37.9)$ \\
\hline Excellent & $10(14.3)$ & $4(3.6)$ & $15(10)$ & $29(8.8)$ \\
\hline \multicolumn{5}{|l|}{ ISP Credibility } \\
\hline No & $17(24.3)$ & - & $32(21.3)$ & $49(14.8)$ \\
\hline Yes & $53(75.7)$ & $110(100)$ & $118(78.7)$ & $281(85.2)$ \\
\hline \multicolumn{5}{|c|}{ ISP Competency/Assurance } \\
\hline No & $19(27.1)$ & - & $31(20.7)$ & $50(15.2)$ \\
\hline Yes & $51(72.9)$ & $110(100)$ & $119(79.3)$ & $280(84.8)$ \\
\hline \multicolumn{5}{|l|}{ Information } \\
\hline No & $40(57.1)$ & $89(80.9)$ & $106(70.7)$ & $235(71.2)$ \\
\hline Yes & $30(42.9)$ & $21(19.1)$ & $44(29.3)$ & $95(28.8)$ \\
\hline \multicolumn{5}{|l|}{ ISP Willingness } \\
\hline No & $19(27.1)$ & - & $46(30.7)$ & $65(19.7)$ \\
\hline Yes & $51(72.9)$ & $110(100)$ & $104(69.3)$ & $265(80.3)$ \\
\hline \multicolumn{5}{|c|}{ Recommendation of ISP } \\
\hline No & $15(21.4)$ & - & $36(24.0)$ & $51(15.5)$ \\
\hline Yes & $55(78.6)$ & $110(100)$ & $114(76)$ & $279(84.5)$ \\
\hline Preference to othe & & & & \\
\hline
\end{tabular}

dissemination. This is important most especially when services are scheduled for routine maintenance or experience unplanned breakdown. 


\begin{tabular}{|c|c|c|c|c|}
\hline No & $26(37.1)$ & - & $54(36.0)$ & $80(24.2)$ \\
\hline Yes & $44(62.9)$ & $110(100)$ & $96(64.0)$ & $250(75.8)$ \\
\hline \multicolumn{5}{|c|}{ Service worth paying for/Tangible } \\
\hline No & $25(35.7)$ & - & $34(22.7)$ & 59 (17.9) \\
\hline Yes & $45(64.3)$ & $110(100)$ & $116(77.3)$ & $271(82.1)$ \\
\hline \multicolumn{5}{|c|}{ Switching of ISP } \\
\hline No & $17(24.3)$ & $110(100)$ & $27(18)$ & $(46.7) 154$ \\
\hline Yes & $53(75.7)$ & - & $123(82)$ & $176(53.3)$ \\
\hline Total & $70(100)$ & $110(100)$ & $150(100)$ & $330(100)$ \\
\hline
\end{tabular}

\section{FURTHER RESEARCH}

Further related studies could be conducted along this path in order to be able to generalise for a wider audience. Most especially increasing the coverage to include more regions out of the six geo-political zones of Nigeria beyond the southwestern region as employed by this study. At the same time, a larger sample size will also make the result more robust and also has the tendency to reveal better inferences. Inclusion of inferential statistics could also be adopted in further studies in order to further establish the outcome the of the findings.

\section{REFERENCES}

[1] Ademola, A. A (2013). The Role of Advanced Networks in the Education of the Future: A Report of Obafemi Awolowo University, Nigeria i-Lab Initiatives. Mediterranean Journal of Social Sciences MCSER Publishing, Rome-Italy, Vol. 4(14), pp. 109-114.

[2] Awoleye, O.M., Siyanbola, W.O. (2006). Examining the level of penetration and impact of Internet usage amongst undergraduate students in Nigerian Universities- A case study approach. Current Development in Technology Assisted Education, Vol 3, pp.1708 -1713.

[3] Awoleye O.M. and Siyanbola W.O. (2007). An Assessment of Students' Preparedness for e-Learning Adoption in Nigerian Universities. The International Journal of Learning. Vol 14 (3), pp. 135-141.

[4] Awoleye, O. M., Siyanbola, W. O. and Oladipo, O. F. (2008). Adoption Assessment of Internet Usage amongst Undergraduates in Nigeria Universities: A Case Study Approach. Journal of Technology Management \& Innovation, Volume 3 (1), pp. 84-89.

[5] Bennett, R., Bove, L., Dann, S., Drennan, J.,

[6] Frazer L., Gabbot, M., Hill, R., Lawley, M., Matear S., Perry, C., Sparks, B., Summer, J., Sweeney, J., Ward, T. and White, L (2002). Service Marketing a Managerial pproach. Australia: John Wiley and Sons, pp. 100-150.

[7] [Bonk, C. J., Lee, M. M., and Reynolds, T. (2009). A Special Passage through Asia E- Learning. AACE. Retrieved October 7, 2016 from http://www.editlib.org

[8] Chakrabarty, A. (2006). Barking up the wrong tree Factors Influencing Customer Satisfaction in Retail Banking in the UK. International Journal of Applied Marketing 1(1): 10-20.
[9] Jagboro, K.O. (2007). A Study of Internet Usage in Nigerian Universities: A case study of Obafemi Awolowo University, Ile-Ife, Nigeria. FirstMonday. Vol $8(2)$

[10] Fogli, L. (2006). Customer Service Delivery. San Francisco, Jossey-Bass. Pp. 40 -100. Gee, R., Coates, G. and Nicholson, M. (2008). Understanding and Profitably Managing Customer Loyalty. Marketing Intelligence and Planning 26(4):359 -374.

[11] Hansemark, O. C. and Albinson, M. (2004). Customer Satisfaction and Retention: The Experiences of Individual with Employees, Managing Service Quality 14(1) 40- 50 .

[12] Kotler, P. and Keller, K. L. (2009). Marketing Management (13th Ed). Pearson Education Inc., Upper Saddle River. New Jersey. USA. pp. 30-50.

[13] Kumar, R. and Kaur, A. (2005). Internet and Its Use in the Engineering Colleges of Punjab India: A Case Study. Webology 2(4): 30-90.

[14] Kumah, C. H. (2015). A Comparative Study of Use of the Library and the Internet as Sources of Information by Graduate Students in the University of Ghana, Library Philosophy and Practice (e-journal) 2(3):10-50.

[15] Mereku, D. K., Yidana, I, Hordzi, W., Tete-Mensah, I., Tete-Mensah, W., and Williams, J. B. (2009). Ghana Report. University of Education, Winneba, Ghana. Pp 50-70.

[16] Ogungbeni, J. I., Adekanye, A.O., Bamigbose, A. A., and Sulaiman, M. A. (2016): Internet Use among Undergraduates in Nigeria: The Role of policy Information and Knowledge Management, Vol.6. 22245758 .

[17] Ogunlade, O. O (2013). Assessment of Internet Service Quality and Customers' Satisfaction in University of Ilorin, Ilorin, Nigeria. Journal of education and Practice, 5(50): $81-86$

[18] Otunla, A. O. (2013). Internet Access and use Among Undergraduate Students of Bow University Iwo, Osun State, Nigeria. Library Philosophy and Practice (ejournal). Retrieved June 15, 2016 from http://digitalcommons.unl.edu libphilprac /964. Pp 100115

[19] Parasuraman, A., Zeithaml, V. A., and Berry, L. L 
(1990). Five Imperative for Improving Service Quality. Sloan Management Review pp.29-38.

[20] Rasli, A., Shekarchizadeh, A., and Iqbal. J. (2012). Perception of Service Quality in Higher Education: Perspective of Iranian Students in Malaysian Universities. International Journal of Academic Research in Management 1(1): 10-25.

[21] Saxena (2017). The role and impact of ICT in improving the quality of Education: An Overview. International Journal of Engineering Sciences \& Research Technology.6 (3): Pp 501-503.

[22] UNESCO Institute for Statistics (2013). Information and communication technology (ICT) in five Arab States: A comparative analysis of ICT integration and e-readiness in schools in Egypt, Jordan, Oman, Palestine and Qatar. Montreal: UIS.

[23] Zeithaml, V. A., Bitner, and M. J. and Gremler, D. D. (2009). Services Marketing: Integrating Customer Focus across the Firm, 5th edition, New York: McGraw- Hill. Pp. 200-205.

[24] Zuzana, K. (2013): Application of Information Technology Service Management within selected Logistics and Transport Services International Conference Reliability and Statistics in Transportation and Communication (RelStat'13), Transport and Telecommunication Institute, Lomonosova 1, LV-1019, Riga, Latvia. 